Revue bibliographique pour le domaine irano-aryen

\title{
«Problems in the Study of Safavid
}

Historiography ». Al-'Usur al-Wusta: The Bulletin of

Middle East Medievalists, 16, 2004, pp. 8-10.

\section{Robert McChesney}

\section{(2) OpenEdition}

1 Journals

\section{Édition électronique}

URL : http://journals.openedition.org/abstractairanica/17991

DOI : 10.4000/abstractairanica. 17991

ISSN : 1961-960X

Éditeur :

CNRS (UMR 7528 Mondes iraniens et indiens), Éditions de l'IFRI

\section{Édition imprimée}

Date de publication : 15 mai 2007

ISSN : 0240-8910

Référence électronique

Robert McChesney, " "Problems in the Study of Safavid Historiography ». Al-'Usur al-Wusta: The Bulletin of Middle East Medievalists, 16, 2004, pp. 8-10. », Abstracta Iranica [En ligne], Volume 28 | 2007, document 192, mis en ligne le 18 septembre 2007, consulté le 25 septembre 2020. URL : http:// journals.openedition.org/abstractairanica/17991; DOI : https://doi.org/10.4000/abstractairanica. 17991

Ce document a été généré automatiquement le 25 septembre 2020.

Tous droits réservés 
«Problems in the Study of Safavid Historiography ». Al-'Usur al-Wusta: The Bulletin of Middle East Medievalists, 16, 2004, pp. 8-10.

Robert McChesney 
1 In this brief article, Prof. Quinn, reiterates her published findings that Safavid chroniclers largely followed earlier works in narrating the past, that the chronicle introduction ( $(\bar{i} b \bar{a} \bar{c} e)$ incorporated formal conventions, and that the chroniclers in narrating near-contemporary events, relied on a variety of sources, both oral and written. Through a meticulous examination of Safavid chronicles she was able to identify the time (the reign of Šāh Ṭahmāsp, 1524-1576) when Safavid history began to be rewritten in order to cast it in a Twelver Shi'i mold. Her further consideration of these issues permits her to raise new questions about the writing of Safavid chronicles: specifically, what were the circumstances under which the revision of Safavid history took place? And for Safavid chroniclers after the first generation, what determined their choice of sources on which to rely for a narrative of the early period? In discussing the dibāaces of chronicles she poses the question: to what degree did the conventional elements of the dibāče determine the actual content of the rest of the chronicle? Her examination of the issue of chroniclers' sources for information contemporary with them shows the independence of sources (for example, although Eskandar Beg, a court secretary, and Jalāl al-Dīn Yazdī, the court astrologer, were writing at the same time, their treatments of the same episodes are sufficiently different to indicate that they had different sources of information). The Author also outlines one of the major problems in getting at the documentary sources used by chroniclers: the absence today of archives from the Safavid period as well as the failure of Safavid chroniclers to reference the archival sources they obviously used. Lastly, she raises a question of importance to all students of historiography in the early modern period: who were the intended audiences for these chronicles and how might that have shaped the narratives.

INDEX

Thèmes : 4.2.1. Safavides et Qâjârs

\section{AUTEURS}

ROBERT MCCHESNEY

University of New York 